\title{
PROBLEMS OF CONFLICT OF INTEREST MANAGEMENT IN THE CIVIL SERVICE SYSTEM
}

\author{
Natalia Likarchuk \\ Doctor of Political Science, Educational and Scientific Institute of Public \\ Administration and Civil Service, Taras Shevchenko National University of Kyiv, Ukraine \\ e-mail: n.likarchuk@gmail.com,orcid.org/0000-0001-7119-439X
}

\author{
Daria Likarchuk \\ Ph.D. in Political Sciences, Master of Philological Sciences, \\ Kyiv National University of Culture and Arts, Ukraine \\ e-mail: likarchukd@gmail.com, orcid.org/0000-0003-1603-7601
}

\section{Inna Shevel}

Ph.D. (Social Sciences), Associate Professor at the Department of International Relations, Kyiv National University of Culture and Arts, Ukraine e-mail: shevelinna@ukr.net orcid.org/0000-0002-6387-2506

\section{Summary}

We offers a solution to problems of conflict of interest management in the civil service system. Conflicts of interest are largely provoked by the implementation of a radical domestic policy of reforms that affect the fundamental interests of most actors in political life. It is in these crisis conditions of "institutional instability" that the articulated interests of the main groups in the struggle to preserve or change their political status are especially evident. The conflict of interests of the ruling elite is resolved by the new strategic course development by the political leadership of the state, which finds its expression in the institutionalization of the political regime within the policy of "consensus". Ukraine implements the European experience and uses international cooperation of developed democracies to study and prevent conflicts of interest, implement international standards, settle political and legal mechanisms to overcome the negative consequences of conflicts in the civil service.

Keywords: conflict, interest management, democracy, political, legal mechanisms, consensus.

DOI: https://doi.org/10.23856/4715

\section{Introduction}

Conflicts in the field of public administration by their specificity are one of the most problematic conflicts that arise due to differences of interest, the struggle for positions.

Contradictions between political and state-administrative structures show the dual nature of the orientations of the macro-government system. In other words, in this case we have a conflict of principles and criteria that, on the one hand, focus the activities of state institutions on the consolidation and stabilization of political power, and on the other it is aimed at macroeconomic regulation of social relations. The beginning of the conflict of interests is associated with a vague division of powers, lack of responsibility. 
The study of conflict of interest in the civil service as a research problem has not received sufficient attention from scholars, which is largely due to the incompleteness of the process of the civil service institutionalization... Conflicts arise in all kinds of human activity and in the field of public administration this is not a drawback. Conflicts have their consequences, the general social nature, affect the state of the social environment of society as a whole. Every person who goes through periods of social growth on the state steps is constantly faced with conflict situations of various kinds. Such a large set of conflict agents leads to a state where conflict is considered an integral part of the life of the individual and his team, the civil service as a whole (Vasiliev, 2009).

Ukraine, unlike the European Union, does not have a solid legal framework to help prevent conflict situations for individuals during the civil service, and this is being discussed very actively recently in our country. In this complex globalized world, no country can protect itself from conflicts of interest in the activities of civil servants. Ukraine implements the European experience and uses international cooperation of developed democracies to study and prevent conflicts of interest, implement international standards, settle political and legal mechanisms to overcome the negative consequences of conflicts in the civil service.

\section{The concept "conflict of interest"}

The purpose of the study is scientific and theoretical justification of the analysis, a mechanism formation for managing and resolving conflicts of interest in professional activities in the civil service, making recommendations for their improvement and developing measures to resolve conflicts manage conflicts of interest and fight corruption.

In the process of scientific research the methods of structural-functional, typological, comparative-historical, legal, statistical, sociological analysis, as well as the methodology of system analysis and synthesis have been used. The normative basis of the study is the current Ukrainian legislation, official documents of the EU, USA, Canada, normative documents of the UN General Assembly.

The concept "conflict of interest" is a category covering the most important aspects of public administration, the scope of general issues of political and the state economic activity, the legal life of society. Conflicts of interest cover personal categories, usually officials who may have a direct interest in political decision-making (Bruno, 2008).

Conflict of interest cannot be studied without a stable definition of "interest". Interest is a person's active position on the use of various objects, which he uses, directs to his own good and to meet certain needs. In the sociological context, the specificity of interest is its position and role in the system of social relations, a factor in determining its activities. Conflict interest arises in the system of consensus and cooperation, which can lead to risks in the civil service.

On the theoretical side, the conflict of interest is clearly defined, but on the practical side it is very difficult to separate the boundaries between conflict in public administration and personal conflict, because interests are not always separated, they are often the same. Status conflict, violation of equality in the relations of the organization, causes great harm to the interests of the state, society and the individual, violates the conditions of competition, access to state resources. (Lopushinsky, 2020).

The main problem of political conflict is centered around its spheres of influence, which includes the management, regulation and control of confrontation (Carney, 1998). Proper organization of conflict management in the modern system of public administration minimizes possible and inevitable moral, economic and other losses and contributes to the best results in the confrontation. 
For example, the 2003 UN Convention against Corruption does not define conflicts of interest. But the articles of this international treaty on the public sector (art. 7), codes of conduct for public officials (art. 8) and the private sector (art. 12) contain provisions, with varying degrees of directiveness, that guide states to take action on prevention and resolution of conflicts of interest in the civil service (Corruption perceptions index, 2020).

Also, the Corruption Perceptions Index highlights the global indicators of corruption and at the same time focuses on the presence of conflicts of interest. Although most countries have made little progress in fighting corruption in a decade, more than two-thirds of countries have below 50 . From bribery and misappropriation and overpricing to favoritism, corruption takes various forms (Corruption perceptions index, 2020).

The Council for the Organization for Economic Co-operation and Development (OECD) is concerned about the ethics of public service conduct and has developed Recommendations for OECD member countries on resolving conflicts of interest in the civil service. They will propose international standards that will help European countries reform their policies, maintain integrity in decision-making, put them into practice, take risks and prevent conflicts in the public sector in their day-to-day work. They supported the opinion of various scholars who believed that a conflict of interest could not be separated from the interests of the individual and his job descriptions. All these points should be taken into account and determined, including sanctions against officials who are personally responsible for compliance with behavioral norms, compliance with state trust in institutions, service to the public interest. All these points should be taken into account and determined, including sanctions against officials who are personally responsible for compliance with behavioral norms, compliance with state trust in institutions, service to the public interest (Recommendation of the OECD Council on Guidelines for Managing).

\section{Corruption and conflict of interest}

Corruption is one of the most difficult areas in Ukraine, which requires a total reform of the civil service and the settlement of conflicts of interest, the corruption risks spread. Це все описано у Explanation of the Ministry of Justice of Ukraine of April 12, 2011 "Corruption risks in the activities of civil servants" (United Nations Convention against Corruption).

Corruption leads to inefficient allocation and expenditure of public funds and resources, slowing economic growth, loss of taxes, reduced investment in production and growing social inequality. As practice shows, at the heart of any corruption offense is a conflict of interest of persons holding public office in the system of public administration and has in connection with the powers granted to them by the state appropriate influence that can be used in their personal interests, including contrary to the interests of the state.

With the establishment of the state body of the National Agency of Ukraine for the Prevention of Corruption (NAPC), statistical information on corruption and conflicts of interest has increased significantly. Offenses related to the prevention and settlement of conflicts of interest are disclosed, this is prescribed in Article 172-7 on violations of the requirements for the prevention of conflicts of interest (Corruption risks in the activities of civil servants).

According to the results of the monitoring survey conducted by the Institute of Sociology of the National Academy of Sciences of Ukraine, it is shown that in 2019 the question: "In your opinion, to what extent are reforms in the field of public administration currently hampered?", among respondents are 44, $\%$ said that a high degree of gallification of public administration reforms, and $32.5 \%$ believe that it is slowed down indirectly. This shows that the state has a low level of response to the problem of public administration and the emergence of conflicts of interest. (see fig 1) (Golovakha, 2019). 


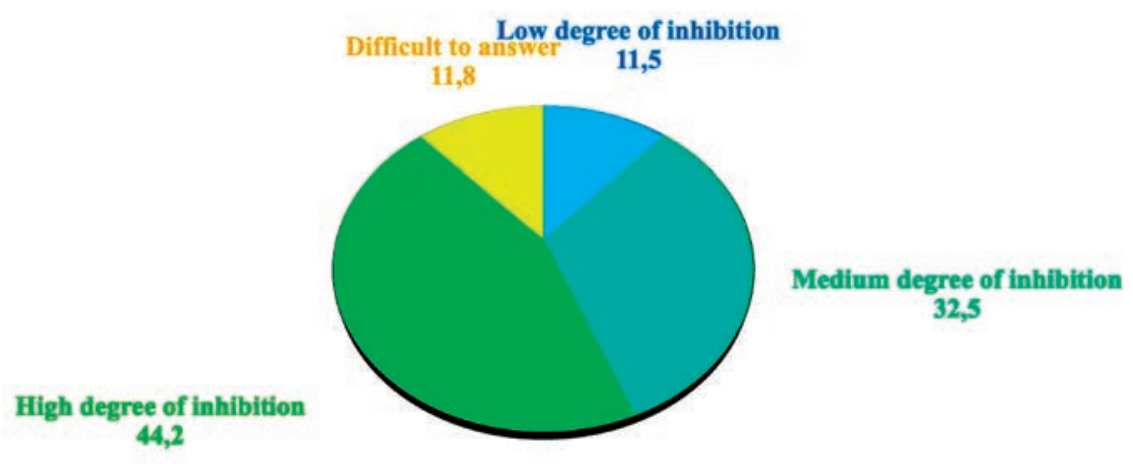

Fig. 1. In your opinion, to what extent are reforms in the field of public administration currently hampered? 2019

The key issue in considering this topic is the emergence of conflicts of interest. Providing these facts grants information on the following research question, which examines the most important causes of conflict of interest in the civil service. According to the respondents, the most acute problem is shown in the answers to the question of another sign: "In your opinion, what are the most important tasks of development and transformation in our society?, among the respondents, $55 \%$ answered that the issue of reducing the level of corruption is relevant, it is quite logical to state this reason, for example, first place, $50.9 \%$ in second place, the importance of equality before the law, and third place is the observance of constitutionally guaranteed rights and human freedoms, which was 38\% (See fig. 2) (Golovakha, 2019).

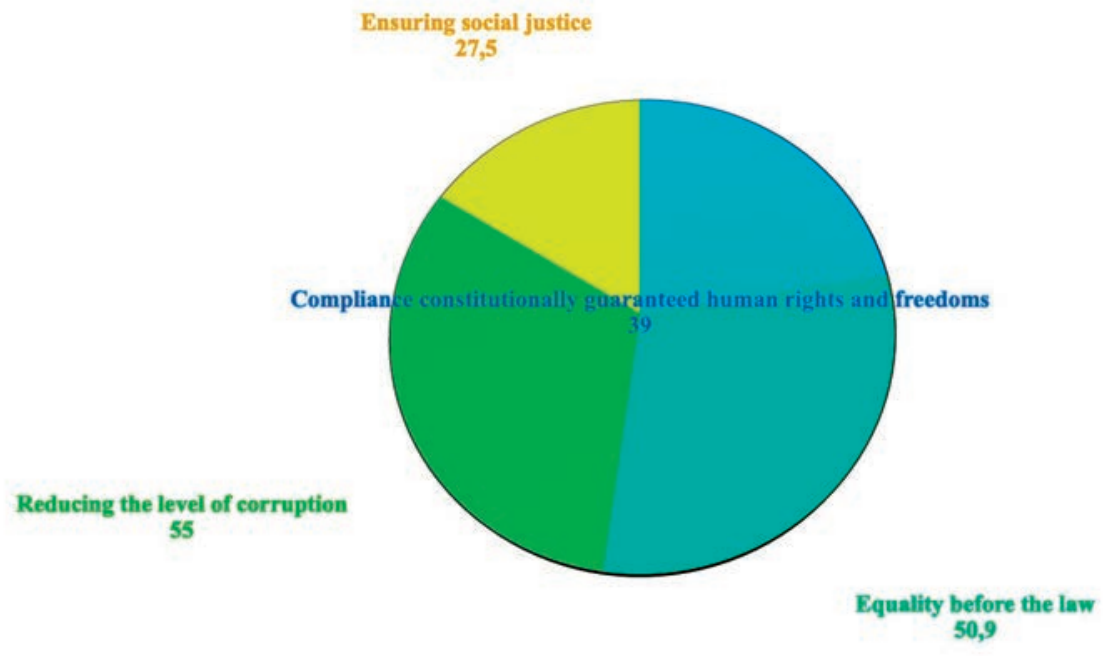

Fig. 2. In your opinion, what are the challenges of development and transformation in are our society most relevant? 2019 
Respondents' answers help to conclude that the mechanism of conflict of interest management does not work to some extent, and sometimes does not apply at all.

Thus, Ukrainian society needs to make considerable efforts to reform and improve the system of conflict of interest management in the civil service and restore confidence in government. Accelerate the reform of national policies for the regulation of conflicts of interest and the corruption prevention; clearly reflect this in regulations to maintain the moral purity of the civil service.

In resolving conflicts of interest, an important role is played by increasing the activity of society, public awareness of what they can expect from civil servants. It is the increase in the role of public control over the activities of civil servants that will create an appropriate social environment against abuses in the civil service. Conflicts of interest, like corruption in general, are largely due to imperfect civil service legislation. Civil servants are not interested in legislating conflicts of interest and establishing responsibilities for promoting conflicts of interest. The scale of such a conflict depends not only on the private interests of civil servants, but also on a number of factors, among which are important legal, economic, political, social.

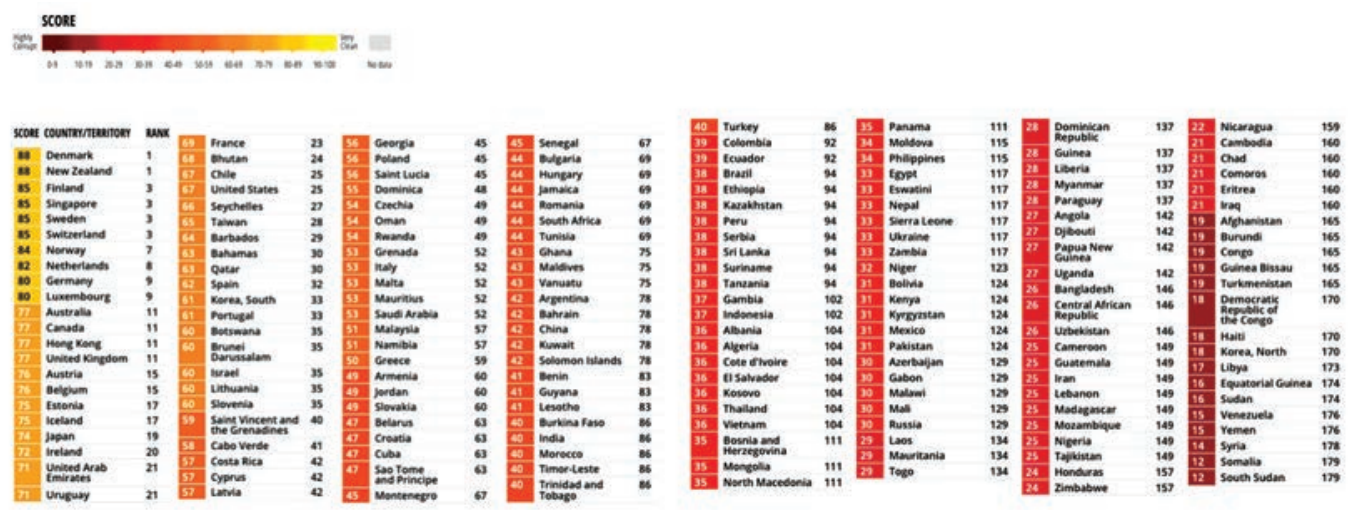

Fig. 3. CORRUPTION PERCEPTIONS INDEX (2020)

Conflict of interest threatens the value of the institution of civil service, negative changes in the legal and social foundations of the state, because in case of conflict of interest:

- public (social) interest is replaced by private interests;

- "the right and the law" are ignored;

- the principles of tolerance, equality and transparency in the use of benefits by civil servants who have access to public resources (material, financial, information) are violated) (McKevitt, 1998).

In accordance with the above, scientists have identified the main mechanisms for resolving conflicts of interest:

- elimination of the source of conflict in the participants relations of the confrontation, reduction of the share of hostility of the subjects, mutual desire to eliminate differences;

- prevention of open-ended political conflicts, such as political decision-making in one's own favor (Likarchuk, 2020). 


\section{A step towards corruption: resolving conflicts of interest (Eidos: Center for Political Studies and Analytics)}

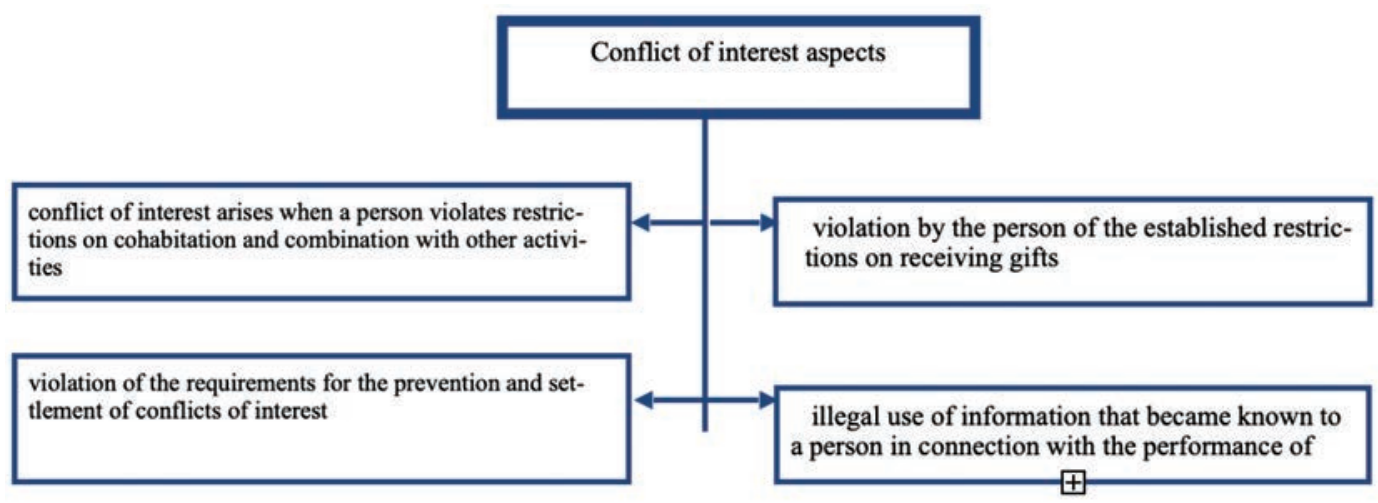

Conflict resolution requires finding new, modern and comprehensive methods. To achieve a balance in resolving conflicts of interest in the civil service, the following conditions must be met:

- first, the parties to the conflict must acknowledge the existence of a conflict situation;

- secondly, in resolving the conflict it is necessary to identify the degree of organization, in order to reach an agreement between the parties and the implementation of current legislation;

- thirdly, certain "rules of the game" must be established, in compliance with which political responsibility is important (Manuel, 2008).

Modern mechanisms for resolving conflicts of interest are based not only on the statutory requirements for timely resolution of conflicts and penalties for non-compliance, but also on the disclosure of potential cases of personal interest and increasing the role of ethics and morality in choosing between private interest and official interest duty. Ethical norms form the behavior standards of an individual in certain circumstances of personal interest, determine the scope of the subject's exercise of the rights granted to him by law and ensure the balance of personal and public interests.

A lot of European Union countries have developed laws and mechanisms to prevent conflicts of interest in the civil service. It has been proposed to create specialized anti-corruption bodies, mechanisms for verifying declarations of assets and interests of senior government officials, security and protection of persons who report on the state of the official's crime. According to the proposals of the European experience, the solution of the problems of conflict of interests in the perspective of three strategies has been covered:

- detection takes place through analysis, studies all the materials lslbistosti and the emergence of a possible conflict of interest, clarifying the role of the victim;

- prevention with the help of established rules and prohibitions to certain activities;

- prevention occurs through removal from the civil service in the event of a conflict of interest, the adoption of a collegial decision on situations involving conflicts of interest (Tokar-Ostapenko, 2013).

The Law of Ukraine of October 14, 2014 №1700-VI “On Prevention of Corruption” (hereinafter the Law of №1700, which entered into force on January 1, 2020) defines the types of concepts such as potential (relatives) and real conflict of interest of civil servants of different levels. 
If we consider two types of conflict together, we can observe in them one belonging to the property interest, which is accompanied by extra-service relations with individuals or legal entities, different types of organizations. Potential interest is a private interest that may prejudice decision-making and abuse of power (Article 1 of the Law). Thus, it characterizes the connection of a person with property or non-property interest, personal, family, friendly, business, which may or may not happen in the future.

Real interest is the opposition between one's own and one's official (service) interest. What affects the objectivity of decision-making during the term of office (Article 1 of the Law). Thus, this conflict characterizes a decision that has already occurred during the identification of private interest.

\section{Conclusions}

Conflicts of interest are largely provoked by the implementation of a radical domestic policy of reforms that affect the fundamental interests of most actors in political life. It is in these crisis conditions of "institutional instability" that the articulated interests of the main groups in the struggle to preserve or change their political status are especially evident. The conflict of interests of the ruling elite is resolved by the new strategic course development by the political leadership of the state, which finds its expression in the institutionalization of the political regime within the policy of "consensus".

Based on the analysis of the situation, conflict management, certain shortcomings in the work of civil servants have been identified:

- lack of a comprehensive and unified approach to the conflict management process;

- the most documents development in the field of conflict of interest management is based on separate decisions of different subjects such as the president, government, parliament;

- lack of regulation of the decision-making process in a situation of conflict of interest;

- underdeveloped mechanisms of control over the actions of civil servants;

- lack of political will for radical changes in this area.

Resolving conflicts of interest as one of the most important means of combating corruption is the difficult organizational and legal work of state bodies, local governments, civil society institutions and citizens themselves. Proper implementation of this activity requires agreed decisions, systematic justification of rational experience and adequate scientific and analytical interpretation of results. For example, U.S. law requires civil servants to provide the Office of Ethics with information about their expenses and income, as well as the expenses and income of relatives, including not only children and husbands (spouses).

Therefore, conflicts of interest will be required in the constant updating of co-regulation mechanisms, and in order to improve the prevention and settlement of conflicts of interest it is necessary:

- increasing information openness;

- further development of systems of administrative and state regulations;

- improving procedures for mandatory notification of conflicts of interest;

- improvement of the order information on the return to work of former public servants.

\section{References}

1. Vasiliev, $V$. (2009). Public administration, Public administration: improvement and development № 3 [in Ukrainian]. 
2. Bruno Speck, W. (2008). Conflict of Interest: Concepts, Rules and Practices regarding Legislators in Latin America. The Latin Americanist, Volume 49 Issue 2.

3. Lopushinsky, I. (2020). Conflict of interest in the civil service: problems of legislative regulation in Ukraine. UK: Kyiv [in Ukrainian].

4. Carney, G. (1998). Conflict of Interest: Legislators, Ministers and Public Official. Study prepared for Transparency International, Berlin.

5. Corruption perceptions index 2020. Transparency International (2021). https://www.transparency.org/en/cpi/2020/index/nzl.

6. Recommendation of the OECD Council on Guidelines for Managing. Conflict of Interest in the Public Service (2021). https://legalinstruments.oecd.org/public/doc/130/130.en.pdf.

7. United Nations Convention against Corruption: International document (2020). https://www.unodc.org/unodc/en/treaties/CAC/.

8. Corruption risks in the activities of civil servants: explanation of the Ministry of Justice of Ukraine (2020). https://www.kmu.gov.ua/en/reformi/verhovenstvo-prava-ta-borotba-z-korupciyeyu/borotba-z-korupciyeyu.

9. Golovakha, Y. (2019). Ukrainian society: monitoring of social changes. NAS of Ukraine. [in Ukrainian].

10. McKevitt, (1998). D. Managing core public service. Core Public Services. Oxford: Blackwell. 11. Likarchuk, N.(2020). Favoritism as a Manifestation of Corruption and Managerial Incompetence. Bulletin of Taras Shevchenko National University of Kyiv. Public Administration, 11(1). [in Ukrainian].

12. Manuel, V. (2008). Conflict of interest policies and practices in nine EU member states. OECD Publishin.

13. Tokar-Ostapenko, O. (2013). Settlement of conflict of interest in the civil service: possibilities of applying the European experience in Ukraine. NISS [in Ukrainian]. 